\title{
COMPARATIVE EVALUATION OF DIFFERENT DOSES OF VINPOCETINE ALONE AND IN COMBINATION WITH SULFASALAZINE IN EXPERIMENTALLY INDUCED INFLAMMATORY BOWEL DISEASE IN RATS
}

\author{
NISHTHA DATT ${ }^{1}$, RAKESH RAMAN PATYAR ${ }^{2}$, SAZAL PATYAR ${ }^{1 *}$ \\ ${ }^{1}$ Department of Pharmacology, School of Pharmaceutical Sciences, Lovely Professional University, Phagwara, Punjab, India. ${ }^{2}$ Department \\ of Biochemistry, Indira Gandhi Medical College, Shimla, Himachal Pradesh, India. Email: sazalpatyar@yahoo.co.in
}

Received: 14 July 2017, Revised and Accepted: 25 July 2017

\begin{abstract}
Objective: Inflammatory bowel disease (IBD) is a disorder characterized by chronic inflammation of the gastrointestinal tract and its exact etiopathology is still unclear. Most of the currently available drugs provide the symptomatic improvement, and their long-term use can lead to various unwanted effects also. This study was done to observe the effects of vinpocetine alone and in combination with sulfasalazine on IBD in rats.

Methods: Adult Wistar rats of either sex were used $(\mathrm{n}=36)$. Experimental colitis was produced by intracolonic administration of acetic acid $(10 \% \mathrm{v} / \mathrm{v}$, $0.20 \mathrm{ml} / \mathrm{rat}$ ) given per rectally. Rats were divided into six groups ( $\mathrm{n}=6)$ : Group I - normal control $(0.9 \% \mathrm{w} / \mathrm{v}$ saline, intracolonic administration + $0.5 \% \mathrm{w} / \mathrm{v}$ carboxymethyl cellulose, i.e., CMC, p.o); Group II - acetic acid (10\% v/v, intracolonic administration $+0.5 \% \mathrm{w} / \mathrm{v}$ CMC, p.o); Group IIIA - acetic acid + vinpocetine (5 mg/kg, p.o); Group IIIB - acetic acid + vinpocetine (10 mg/kg, p.o); Group IV - acetic acid + sulfasalazine (360 mg/kg, p.o.); Group V - acetic acid + sulfasalazine + vinpocetine $(360 \mathrm{mg} / \mathrm{kg}$, p.o. $+5 \mathrm{mg} / \mathrm{kg}$, p.o). The study period was of 15 days in which animals were treated with acetic acid solution on day 1 and treatment was started $4 \mathrm{hrs}$ after the administration of acetic acid till the $14^{\text {th }}$ day. On $15^{\text {th }}$ day, the animals were sacrificed for the investigation of various macroscopic, microscopic, and biochemical parameters.
\end{abstract}

Results: The higher dose of orally administered vinpocetine $(10 \mathrm{mg} / \mathrm{kg})$ and combination of sulfasalazine + vinpocetine $(360 \mathrm{mg} / \mathrm{kg}+5 \mathrm{mg} / \mathrm{kg}) \mathrm{were}$ found to be the most effective in reducing the severity of mucosal damage which was similar to the reference drug sulfasalazine ( $360 \mathrm{mg} / \mathrm{kg})$. Both the doses of vinpocetine curtailed the histopathological scores. The combination therapy of sulfasalazine + vinpocetine $(360 \mathrm{mg} / \mathrm{kg}+5 \mathrm{mg} / \mathrm{kg})$ was equally effective to standard drug but not found to be the most effective treatment. Myeloperoxidase levels were significantly reduced in vinpocetine treated groups as compared to acetic acid control group, while the glutathione levels were increased significantly. Similarly, vinpocetine significantly decreased the malondialdehyde level in the intestinal tissue of the rats with acetic acid induced colitis, and thus the severity of the tissue damage.

Conclusion: The results of this study indicated that vinpocetine possesses anti-inflammatory activity and are therapeutically effective in acetic acid induced ulcerative colitis at a dose of $5 \mathrm{mg} / \mathrm{kg}$. More pronounced effects were observed at higher dose, i.e., $10 \mathrm{mg} / \mathrm{kg}$. The combination of sulfasalzine + vinpocetine was also found to be effective as compared to high dose of vinpocetine $(10 \mathrm{mg} / \mathrm{kg})$.

Keywords: Crohn's disease, Ulcerative colitis, Diagnosis, Treatment, Chronic disease, Tumor necrosis factor, Myeloperoxidase, Malondialdehyde, Interleukin-1.

(c) 2017 The Authors. Published by Innovare Academic Sciences Pvt Ltd. This is an open access article under the CC BY license (http://creativecommons. org/licenses/by/4. 0/) DOI: http://dx.doi.org/10.22159/ajpcr.2017.v10s4.21343

\section{INTRODUCTION}

Inflammatory bowel disease (IBD) is a disorder characterized by chronic inflammation of the gastrointestinal tract. There are two clinical subtypes, ulcerative colitis (UC), and Crohn's disease (CD). UC is limited to the colon (large intestine) while CD can involve any part of the gastrointestinal tract from the mouth to the anus and it most commonly affects the small intestine and/or the colon $[1,2]$. The pathogenesis of IBD remains unclear, but imbalance between proinflammatory cytokines, such as tumor necrosis factor- $\alpha$ (TNF- $\alpha$ ), interferon- $\Upsilon$, interleukin-1 (IL-1), IL-6, and IL-12, and antiinflammatory cytokines, such as IL-4, IL-10, IL-11, is believed to play a central role in modulation of inflammation [3]. TNF- $\alpha$ and IL-1 upregulate the adhesion molecules and also activate the adaptive immune system of the bowel by recruiting and activating neutrophils and macrophages, causing the adherence of neutrophils to endothelium. Further release of IL-8 causes degranulation of the toxic proteases and reactive oxygen species by attracting activated neutrophils and hence leading to ulceration of intestine [3]. Increased lipid peroxidation and neutrophil degranulation leading to release of malondialdehyde (MDA) and myeloperoxidase (MPO) are the most common characteristics involved in the pathophysiology of IBD [4].
Conventional therapeutic agents such as 5-aminosalicylates (5-ASA) and corticosteroids are still used to treat IBD. In addition, some immunomodulators, such as azathioprine and 6-mercaptopurine, anti-inflammatory drugs and antibiotics are becoming important in the setting of steroid resistant and steroid-dependent patients [5]. However, all of these drugs have shortcomings. For instance, the use of all nonsteroidal anti-inflammatory drugs, selective and nonselective, is associated with a range of potential adverse effects, including an increased risk of adverse cardiovascular effects [6]. Sulfasalazine yields the metabolite sulfapyridine which gives rise to side effects such as agranulocytosis and hypospermia [7]. Its 5-ASA derivative mesalazine has overcome these side effects but it is very expensive. Thus, there is an urgent need of a drug with minimal adverse effects which can be used effectively.

Vinpocetine is a neuroprotective drug used to enhance memory and is given as supplement to patients suffering from cerebrovascular diseases. It is a derivative of periwinkle plant whose antiinflammatory activity has been proved recently [8]. It inhibits TNF- $\alpha$ induced nuclear factor kappa-light-chain-enhancer of activated B cells (NF- $\mathrm{BB}$ ) activation of proinflammatory mediators such as cytokines, chemokines, and adhesion molecules therefore halting 
the inflammation [9]. Vinpocetine has previously been reported as a cyclic phosphodiesterase-1 inhibitor, which also contributes in its anti-inflammatory action [10]. As the pathogenesis of IBD involves the potential role of TNF- $\alpha$ and NF- $\mathrm{BB}$, evidence of their inhibition by vinpocetine indicates that it may be a unique anti-inflammatory agent with potential in treatment of many inflammatory diseases like IBD. No major adverse effect of vinpocetine has been reported yet, which signifies its advantage over other anti-inflammatory drugs. It has been proved effective in treatment of hepatic damage, but no evidence has been reported till date for its use in the treatment of IBD [11]. Hence, this study was conducted to evaluate the effect of different doses of vinpocetine alone and in combination with sulfasalazine in experimentally induced IBD in rats.

\section{METHODS}

This study was conducted in the Department of Pharmacology, Lovely School of Applied Medical Sciences, Lovely Professional University, Phagwara and Akal College of Pharmacy and Technical Education, Mastuana Sahib, Sangrur.

\section{Experimental animals}

This was done as per the guidelines of Indian Council of Medical Research and was approved by Institutional Animal Ethics Committee (ATRC/11/2013). Adult Wistar rats of either sex weighing between 150 and $250 \mathrm{~g}$ were procured from the institute's central animal house. The animals were housed in standard laboratory conditions at $25 \pm 2^{\circ} \mathrm{C}$ and $12 \mathrm{hrs} \mathrm{light}$ and dark cycle. Animals were given free access to rat chow diet and water ad libitum. Before conducting experiments, animals were acclimatized to laboratory conditions for 7 days.

\section{Drugs and chemicals}

Drugs and chemicals needed for this study included vinpocetine (Cebon India Limited, New Delhi), acetic acid, and sulfasalazine (Jackson labs, Amritsar).

\section{Experimental design and groups}

A total of 36 animals were included in the study. Animals were divided into five groups (n=6): I, II, III, IV and V. Group III was subdivided into two subgroups: IIIA and IIIB. Each subgroup had six animals. Groups were as follows:

\begin{tabular}{|c|c|c|}
\hline Groups & Treatment & Dosage \\
\hline$I$ & $\begin{array}{l}\text { Normal saline } \\
(0.5 \% \mathrm{CMC})\end{array}$ & $\begin{array}{l}0.9 \% \mathrm{w} / \mathrm{v} \text { normal saline }(0.2 \mathrm{ml} / \mathrm{rat} \text {, } \\
\text { intracolonic administration })+ \\
0.5 \% \mathrm{w} / \mathrm{v} \text { CMC, p.o. }\end{array}$ \\
\hline II & $\begin{array}{l}\text { Acetic acid } \\
(0.5 \% \mathrm{CMC})\end{array}$ & $\begin{array}{l}10 \% \mathrm{v} / \mathrm{v}, 0.2 \mathrm{ml} / \mathrm{rat} \text {, intracolonic } \\
\text { administration }+0.5 \% \mathrm{w} / \mathrm{v} \text { CMC, p.o. }\end{array}$ \\
\hline IIIA & $\begin{array}{l}\text { Acetic acid+ } \\
\text { vinpocetine }\end{array}$ & $\begin{array}{l}10 \% \mathrm{v} / \mathrm{v}, 0.2 \mathrm{ml} / \mathrm{rat} \text {, intracolonic } \\
\text { administration }+5 \mathrm{mg} / \mathrm{kg} \text {, p.o. }\end{array}$ \\
\hline IIIB & $\begin{array}{l}\text { Acetic acid+ } \\
\text { vinpocetine }\end{array}$ & $\begin{array}{l}10 \% \mathrm{v} / \mathrm{v}, 0.2 \mathrm{ml} / \mathrm{rat} \text {, intracolonic } \\
\text { administration }+10 \mathrm{mg} / \mathrm{kg} \text {, p.o. }\end{array}$ \\
\hline IV & $\begin{array}{l}\text { Acetic acid+ } \\
\text { sulfasalazine }\end{array}$ & $\begin{array}{l}10 \% \mathrm{v} / \mathrm{v}, 0.2 \mathrm{ml} / \mathrm{rat} \text {, intracolonic } \\
\text { administration }+360 \mathrm{mg} / \mathrm{kg} \text {, p.o. }\end{array}$ \\
\hline V & $\begin{array}{l}\text { Acetic acid+ } \\
\text { vinpocetine+ } \\
\text { sulfasalazine }\end{array}$ & $\begin{array}{l}10 \% \mathrm{v} / \mathrm{v}, 0.2 \mathrm{ml} / \mathrm{rat} \text {, intracolonic } \\
\text { administration+least effective dose of } \\
\text { vinpocetine from Group III+ } \\
360 \mathrm{mg} / \mathrm{kg} \text {, p.o }\end{array}$ \\
\hline
\end{tabular}

\section{Induction of colitis}

Experimental colitis was induced by intracolonic administration of acetic acid $(10 \% \mathrm{v} / \mathrm{v}, 0.2 \mathrm{ml} / \mathrm{rat})$ given per rectally. Rats were observed for 15 days and at the end of 15 days, about $1 \mathrm{ml}$ blood was collected. Then, rats were sacrificed under ether anesthesia by cervical dislocation for assessment of various parameters [12] such as assessment of intestinal inflammation, histological analysis, glutathione (GSH) assay, MPO estimation, and MDA assay.

\section{Severity assessment of colitis}

\section{Macroscopic assessment of colitis}

A disease activity index (DAI) was determined in animals by monitoring the clinical symptoms of colitis: Change in body weight, stool consistency and rectal bleeding on day $0,7^{\text {th }}$, and $14^{\text {th }}$ day of treatment period [13]. The severity of colitis was quantified by a clinical scoring system assessing the weight loss, stool consistency, and the fecal occult blood [14] as shown below. The scoring of stool consistency and rectal bleeding was done by two investigators in a blinded fashion.

\section{Scoring system of DAI}

\begin{tabular}{llll}
\hline Score & $\begin{array}{l}\text { Weight } \\
\text { loss } \%\end{array}$ & Stool consistency & Rectal bleeding/Melena \\
\hline 0 & None & Normal & Negative hemoccult \\
1 & $1-5$ & Soft but still formed & $\begin{array}{l}\text { Positive hemoccult } \\
\text { Blood traces in the stool } \\
\text { visible/Melena }\end{array}$ \\
2 & $5-10$ & Very soft & Gross bleeding \\
& & & - \\
\hline & $10-20$ & Liquid stool & \\
\hline
\end{tabular}

\section{Assessment of inflammation}

After sacrificing the animals, the distal $10 \mathrm{~cm}$ of the colon was quickly excised and was freed of adherent adipose tissue. It was washed with normal saline to clean the fecal contents and was examined for gross inflammatory changes. Gross inflammatory index was assessed for inflammation according to scores described by Kojima et al. [15].

Enteritis gross morphology score:

- 0 - No visible damage in the colon and rectal mucosa

- 1 - Mild erythema and oedema of the mucosa

- 2 - Moderate erythema, edema, friability with superficial mucosal ulceration or erosion

- 3 - Marked erythema, edema and well-developed mucosal ulcers

The tissue was incubated in Tris buffer for $30 \mathrm{~min}$ at $37^{\circ} \mathrm{C}$ in shaking water bath $(1 \mathrm{ml} / 100 \mathrm{mg}$ tissue) following which the colon was dissected longitudinally into three pieces for histological analysis, MPO assay, and MDA assay.

\section{Histopathological analysis}

All the groups were subjected to histological examination. It was done by a qualified pathologist using hemotoxylin and eosin staining in a blinded fashion using following score [16].

Histological grading:

- 0 - Normal mucosa with normal amount of inflammatory cells

- 1 - Mild increase in mixed inflammatory cells including scattered neutrophils in lamina propria with occasional cryptitis or crypt abscesses

- 2 - Focal superficial ulceration of the mucosa with moderate increase in inflammatory cells with occasional cryptitis and crypt abscesses

- 3 - Deep mucosal ulceration and heavy mucosal inflammation with cryptitis and crypt abscesses

- 4 - Large or extensive areas of diffuse or extensive deep mucosal ulceration with hemorrhagic necrosis of muscularis mucosa, submucosa or muscularis propria.

\section{Biochemical estimation}

\section{Estimation of reduced GSH activity}

Colonic mucosa was used for biochemical estimations. $1 \mathrm{ml}$ of supernatant was precipitated with $4 \%$ sulfosalicylic acid and cold digested at $4^{\circ} \mathrm{C}$ for $1 \mathrm{hr}$ [17]. The sample was centrifuged at $12,000 \mathrm{rpm}$ for 15 minutes at $4^{\circ} \mathrm{C}$. To $1 \mathrm{ml}$ of this supernatant, $2.7 \mathrm{ml}$ of phosphate buffer (0.1 M, pH 8) and $0.2 \mathrm{ml}$ of 5,5-dithiobis (2-nitrobenzoic acid) were added. This addition of chemical to the supernatant results in the development of yellow color which was read at $412 \mathrm{~nm}$ using a spectrophotometer and the amount of GSH was determined from the 
standard calibration curve of GSH and expressed as nM of GSH reduced per g of tissue protein.

\section{MPO assay}

The infiltration of the mucosa with neutrophils was quantified by the MPO assay. Colon MPO activity was determined photometrically using $3,3,5$, 5 tetramethylbenzidine (TMB) as a substrate [18]. Colon tissue was homogenized in $50 \mathrm{mM}$ phosphate buffer $(\mathrm{pH}=5.4)$, containing $5 \mathrm{~g} / \mathrm{L}$ hexadecyltrimethylammonium bromide $(1 \mathrm{ml})$, thoroughly mixed and centrifuged (10 minutes, $9700 \mathrm{rpm}$ ). The reaction mixture contained supernatant $(20 \mu \mathrm{l})$, TMB $(1.6 \mathrm{mM}, 10 \mu \mathrm{l}), \mathrm{H}_{2} \mathrm{O}_{2}(3.0 \mathrm{mM}$, $20 \mu \mathrm{l})$ and $50 \mathrm{mM}$ phosphate buffer, pH $5.4(150 \mu \mathrm{l})$. The reaction was started by addition of $\mathrm{H}_{2} \mathrm{O}_{2}$ and ended 3 minutes later with addition of $\mathrm{H}_{2} \mathrm{SO}_{4}(2 \mathrm{M}, 10 \mu \mathrm{l})$. The measurement was performed at $450 \mathrm{~nm}$ and MPO expressed as $\mu \mathrm{mol}$ of TMB per mg of tissue protein.

\section{MDA assay}

Lipid peroxidation represents tissue injury due to inflammation. Excessive lipid peroxidation leads to increase in MDA level. Therefore, measuring MDA levels gives an indirect estimation of lipid peroxidation. Assay was done by ferrous sulfate method to assess the lipid peroxidation in the colonic mucosal scrapping [19]. Colonic mucosal scrapping amounting to $700 \mathrm{mg}$ was minced with a mixture of $0.5 \mathrm{ml}$ of sodium dodecyl sulphate, $4 \mathrm{ml} \mathrm{H}_{2} \mathrm{SO}_{4}$ and $1 \mathrm{ml}$ of thiobarbituric acid in a test tube. The mixture was placed in a boiling water bath at $90^{\circ} \mathrm{C}$ for $1 \mathrm{hr}$. After cooling to room temperature the tubes were centrifuged at $2000 \mathrm{rpm}$ for 10 minutes, the optical density of the supernatant fluid was analyzed spectrophotometrically at $535 \mathrm{~nm}$. The extinction coefficient of $1.56 \times 10^{5}$ was used to calculate the amount of MDA formed.

\section{Cytokine estimation}

The levels of TNF- $\alpha$ in plasma were estimated using enzyme-linked immunosorbent assay kits as per the directions of the manufacturer.

\section{Statistical analysis}

Data were expressed as mean \pm standard error of mean. One-way analysis of variance followed by appropriate post hoc test (Bonferonni's test) was used for analysis. $\mathrm{p}<0.05$ was considered as statistically significant.

\section{RESULTS}

\section{Severity assessment of colitis}

\section{Macroscopic assessment of colitis}

The DAI was determined by combining the individual scores of $\%$ weight loss, stool consistency, and rectal bleeding on day 14 of acetic acid administration, divided into 3 . Table 1 reveals the scores of $\%$ weight loss, stool consistency, and rectal bleeding of different experimental groups.

Maximum \% weight loss was observed in acetic acid administered rats without any treatment. Fecal consistency and fecal occult blood of each animal were assessed daily. The acetic acid control group had liquid stools or diarrhea along with fecal occult or gross rectal bleeding which significantly increased the DAI score $(\mathrm{p}<0.05)$ as compared to the healthy group. All treatments (except vinpocetine $5 \mathrm{mg} / \mathrm{kg}$ ) given along with acetic acid administration showed a significant $(\mathrm{p}<0.05)$ decrease in DAI scores as compared with acetic acid control group. However, administration of vinpocetine $(10 \mathrm{mg} / \mathrm{kg})$ and combination of sulfasalazine + vinpocetine $(360 \mathrm{mg} / \mathrm{kg}+5 \mathrm{mg} / \mathrm{kg}$ ) were found to be most effective intervention in alleviating the severity of acetic acid induced UC $(\mathrm{p}<0.05)$, and results were comparable with the sulfasalazine used as standard drug.

\section{Assessment of inflammation}

Mean enteritis gross morphology score was assessed for inflammation (Table 2).

It was observed that vinpocetine has shown its anti-inflammatory effect at both low and high dose. Of the two doses, the higher dose of orally administered vinpocetine $(10 \mathrm{mg} / \mathrm{kg})$ and combination of sulfasalazine + vinpocetine $(360 \mathrm{mg} / \mathrm{kg}+5 \mathrm{mg} / \mathrm{kg})$ were found to be the most effective in reducing the severity of mucosal damage significant at $\mathrm{p}<0.01$ similar to the reference drug: 5-ASA (360 mg/kg). The lowest dose of vinpocetine $(5 \mathrm{mg} / \mathrm{kg}$ ) was moderately effective in reducing the ulceration, edema, erosion and tissue necrosis in colon (Score=3).

\section{Histopathological analysis}

Histopathological damage evaluated by the grading method is represented in Table 3.

The occurrence of colitis was confirmed on the basis of histological damage, cell infiltration, and loss of crypts as shown in Fig. 1.

Vinpocetine ( $5 \mathrm{mg} / \mathrm{kg}$ ) was not completely effective in reversing the cell damage, ulceration and cell infiltration but vinpocetine $(10 \mathrm{mg} / \mathrm{kg})$ and combination of sulfasalazine +vinpocetine $(360 \mathrm{mg} / \mathrm{kg}+5 \mathrm{mg} / \mathrm{kg})$ were effective in reversing the effects caused by acetic acid and thus helped in maintaining the normal histology of colon tissue. The crypt loss in acetic acid control was found to be more than 70\% (approximately) indicating destruction of tissue. Sulfasalazine at $360 \mathrm{mg} / \mathrm{kg}$ dose was effective in maintaining the normal architecture of crypts.

\section{Biochemical estimations}

\section{Estimation of GSH level in colon tissue}

Table 4 shows the effect of different pharmacological interventions on reduced GSH in acetic acid induced colitis in rats after 14 days at treatments. The level of GSH in acetic acid control $(13.61 \pm 0.39)$ was significantly lower $(\mathrm{p}<0.01)$ than the healthy control rats $(33.31 \pm 0.60)$. Administration of vinpocetine $(5 \mathrm{mg} / \mathrm{kg}$ ) was moderately effective in reversing the fall in GSH level as compared to healthy and acetic acid control. Vinpocetine at $10 \mathrm{mg} / \mathrm{kg}$ was very effective treatment compared to acetic acid control ( $\mathrm{p}<0.01$ ), and the results were comparable with the healthy control. Sulfasalazine $(360 \mathrm{mg} / \mathrm{kg}$ ) was most effective treatment compared to acetic acid control group. The combination of sulfasalazine + vinpocetine at $360 \mathrm{mg} / \mathrm{kg}+5 \mathrm{mg} / \mathrm{kg}$ was almost equally effective to

Table 1: DAI of different experimental groups on day 14

\begin{tabular}{|c|c|c|c|c|c|}
\hline S.No. & Experimental groups & $\begin{array}{l}\text { Score of } \% \text { weight } \\
\text { loss }\end{array}$ & $\begin{array}{l}\text { Score of stool } \\
\text { consistency }\end{array}$ & $\begin{array}{l}\text { Score of rectal } \\
\text { bleeding }\end{array}$ & DAI \\
\hline 1 & Normal control & 1 & 0 & 0 & $0.33 \pm 0$ \\
\hline 2 & Acetic acid control & 3 & 3 & 3 & $3 \pm 0^{\mathrm{a}, \mathrm{c}, \mathrm{f}}$ \\
\hline 3 & Acetic acid $+5 \mathrm{mg} / \mathrm{kg}$ vinpocetine & 2 & 2 & 1 & $1.8 \pm 0.16^{\mathrm{a}, \mathrm{c}}$ \\
\hline 4 & Acetic acid $+10 \mathrm{mg} / \mathrm{kg}$ vinpocetine & 1 & 0 & 0 & $0.3 \pm 0.16^{\mathrm{b}}$ \\
\hline 5 & Acetic acid $+360 \mathrm{mg} / \mathrm{kg}$ sulfasalazine & 1 & 0 & 0 & $0.33 \pm 0^{\mathrm{b}, \mathrm{e}}$ \\
\hline 6 & Acetic acid $+360 \mathrm{mg} / \mathrm{kg}$ sulfasalazine $+5 \mathrm{mg} / \mathrm{kg}$ vinpocetine & 1 & 0 & 0 & $0.38 \pm 0.16^{\mathrm{b}, \mathrm{e}}$ \\
\hline
\end{tabular}

The values were expressed as mean \pm standard error of mean. ${ }^{\mathrm{a}} \mathrm{p}<0.05$, when compared with healthy control. ${ }^{\mathrm{b}} \mathrm{p}<0.05$, when compared with acetic acid control, ${ }^{\mathrm{c} p}<0.05$ when compared with sulfasalazine, ${ }^{\mathrm{e}} \mathrm{p}<0.05$, when compared with vinpocetine $5 \mathrm{mg} / \mathrm{kg},{ }_{\mathrm{p}}^{\mathrm{f}}<0.05$, when compared with sulfasalazine+vinpocetine $(360 \mathrm{mg} / \mathrm{kg}+5 \mathrm{mg} / \mathrm{kg})$ The data were analyzed using one-way analysis of variance followed by Dunnett test. DAI: Disease activity index 
sulfasalazine when compared to acetic acid control $(\mathrm{p}<0.01)$ and healthy control. The \% decrease in GSH level was $59.14 \%$ in acetic acid control rats as compared to healthy control whereas in the treated groups vinpocetine $(5 \mathrm{mg} / \mathrm{kg}$ ) exhibited the \% decrease as $19.6 \%$. Similarly, the $\%$ decrease in sulfasalazine treated rats at $360 \mathrm{mg} / \mathrm{kg}$, vinpocetine treated rats at $10 \mathrm{mg} / \mathrm{kg}$, and combination group of sulfasalazine + vinpocetine $(360 \mathrm{mg} / \mathrm{kg}+5 \mathrm{mg} / \mathrm{kg}$ ) were found to be $9.6 \%, 14.12 \%$, and $10.21 \%$, respectively, which indicated the improvement in GSH level as compared to acetic acid rats as shown in Table 4.

\section{Estimation of MPO level in colon tissue}

The level of MPO in acetic acid control $(41.76 \pm 0.774)$ was significantly higher $(\mathrm{p}<0.01)$ than the healthy control rats $(4.95 \pm 0.36)$. Vinpocetine

Table 2: Mean enteritis gross morphology score of different experimental groups

\begin{tabular}{lll}
\hline S.No. & Experimental groups & Score $($ mean \pm SEM) \\
\hline 1 & Normal control & $0^{* \mathrm{~b}, * \mathrm{e}}$ \\
2 & Acetic acid control & $2.83 \pm 0.16^{* \mathrm{a}, * \mathrm{~d}, * \mathrm{c}, * \mathrm{f}}$ \\
3 & Acetic acid $+5 \mathrm{mg} / \mathrm{kg}$ vinpocetine & $1.67 \pm 0.21^{* \mathrm{a}, * \mathrm{c}}$ \\
4 & Acetic acid $+10 \mathrm{mg} / \mathrm{kg}$ vinpocetine & $0.83 \pm 0.30^{* \mathrm{~b}}$ \\
5 & Acetic acid $+360 \mathrm{mg} / \mathrm{kg}$ sulfasalazine & $0.33 \pm 0.21^{* \mathrm{~b}, * \mathrm{e}}$ \\
6 & Acetic acid $+360 \mathrm{mg} / \mathrm{kg}$ & $0.66 \pm 0.33^{* \mathrm{~b}}$ \\
& sulfasalazine+5 $\mathrm{mg} / \mathrm{kg}$ vinpocetine & \\
\hline
\end{tabular}

Sulfasalazine was used as standard. The values were expressed as mean \pm SEM. ${ }^{* a} \mathrm{p}<0.01$, when compared with healthy control. ${ }^{* \mathrm{~b}} \mathrm{p}<0.01$, when compared with acetic acid control, ${ }^{*} \mathrm{p}<0.01$, when compared with 5 -ASA, ${ }^{* \mathrm{~d}} \mathrm{p}<0.01$, when compared with vinpocetine $10 \mathrm{mg} / \mathrm{kg}$, ${ }^{* e} \mathrm{p}<0.01$, when compared with vinpocetine $5 \mathrm{mg} / \mathrm{kg}$ and ${ }^{* \mathrm{f}}$ when compared with sulfasalazine $+5 \mathrm{mg} / \mathrm{kg}$ vinpocetine. The data were analyzed using one-way analysis of variance followed by Dunnett test. SEM: Standard error of mean

Table 3: Mean histopathological score of colon tissue in different experimental groups

\begin{tabular}{lll}
\hline S.No. & Experimental groups & Score $($ mean \pm SEM) \\
\hline 1 & Normal control & $0.00 \pm 0.00^{\mathrm{b}, * \mathrm{c}, * \mathrm{~d}, * \mathrm{e}, * \mathrm{f}}$ \\
2 & Acetic acid control & $4.00 \pm 0.00^{* \mathrm{a}, * \mathrm{c}, * \mathrm{~d}, *_{\mathrm{e}}, * \mathrm{f}}$ \\
3 & Acetic acid $+5 \mathrm{mg} / \mathrm{kg}$ vinpocetine & $2.16 \pm 0.16^{* \mathrm{a}, * \mathrm{~b}, * \mathrm{c}, * \mathrm{~d}, * \mathrm{f}}$ \\
4 & Acetic acid $+10 \mathrm{mg} / \mathrm{kg}$ vinpocetine & $0.83 \pm 0.16^{* \mathrm{a}, * \mathrm{~b}, * \mathrm{e}}$ \\
5 & Acetic acid+360 $\mathrm{mg} / \mathrm{kg}$ sulfasalazine & $0.83 \pm 0.16^{* \mathrm{a}, * \mathrm{~b}, * \mathrm{e}}$ \\
6 & Acetic acid $+360 \mathrm{mg} / \mathrm{kg}$ & $0.83 \pm 0.16^{* \mathrm{a}, * \mathrm{~b}, * \mathrm{e}}$ \\
& sulfasalazine+5 $\mathrm{mg} / \mathrm{kg}$ vinpocetine & \\
\hline
\end{tabular}

The values were expressed as mean \pm SEM. ${ }^{* a} \mathrm{p}<0.01$, when compared with healthy control. ${ }^{* \mathrm{~b}} \mathrm{p}<0.01$, when compared with acetic acid control, ${ }^{* c} \mathrm{p}<0.01$, when compared with 5 -ASA, ${ }^{* \mathrm{~d}} \mathrm{p}<0.01$, when compared with vinpocetine $10 \mathrm{mg} / \mathrm{kg},{ }^{* e} \mathrm{p}<0.01$, when compared with vinpocetine $5 \mathrm{mg} / \mathrm{kg}$ and ${ }^{* f}$ when compared with sulfasalazine $+5 \mathrm{mg} / \mathrm{kg}$ vinpocetine. The data were analyzed using one-way analysis of variance followed by Dunnett test. SEM: Standard error of mean administration at 5 and 10 showed a significant difference $(\mathrm{p}<0.01)$ in MPO levels as compared to healthy and standard groups. Combination of sulfasalazine + vinpocetine at $360 \mathrm{mg} / \mathrm{kg}+5 \mathrm{mg} / \mathrm{kg}$ was moderately effective compared to acetic acid control $(\mathrm{p}<0.01)$, and results were comparable with the healthy control (Table 4). The \% increase in MPO level of acetic acid group was found to be $88.14 \%$. Whereas, sulfasalazine at $360 \mathrm{mg} / \mathrm{kg}$ was very effective treatment with $17.0 \%$ increase in MPO level as compared to acetic acid control group. The vinpocetine administrated at $5 \mathrm{mg} / \mathrm{kg}$ exhibited the \% increase $55.69 \%$ as compared with acetic acid control group. Similarly, the \% increase in MPO level in higher dose of vinpocetine $(10 \mathrm{mg} / \mathrm{kg})$ and combination of sulfasalazine + vinpocetine treated rats at $360 \mathrm{mg} / \mathrm{kg}+5 \mathrm{mg} / \mathrm{kg}$ were found to be $32.11 \%$ and $35.10 \%$, respectively, which indicated the improvement in MPO level as compared to acetic acid treated rats.

\section{Estimation of MDA level in colon tissue}

The level of MDA in acetic acid control $(15.95 \pm 0.563)$ was significantly higher $(\mathrm{p}<0.05)$ than the healthy control rats $(5.66 \pm 0.236)$. Vinpocetine administration at $5 \mathrm{mg} / \mathrm{kg}$ was moderately effective in reversing the rise in MDA level as compared to healthy and acetic acid control (Table 4). The higher dose of vinpocetine $(10 \mathrm{mg} / \mathrm{kg})$ and combination of sulfasalazine + vinpocetine at $360 \mathrm{mg} / \mathrm{kg}+5 \mathrm{mg} / \mathrm{kg}$ were significant $\mathrm{p}<0.05$ as compared to acetic acid group.

\section{Cytokine estimation}

Results of this study indicated that TNF- $\alpha$ levels were significantly increased in acetic acid group as compared to control group (Table 3). Treatment with vinpocetine significantly reduced the TNF- $\alpha$ levels as compared to acetic acid group $(\mathrm{p}<0.05)$.

\section{DISCUSSION}

Acetic acid-induced model is a well established and highly reproducible model for the IBD as it mimics the human disease. It bears close resemblance to human IBD in terms of pathogenesis, histopathological features, and inflammatory mediator profile [20]. Vinpocetine is a neuroprotective drug used to enhance memory and given as supplement to patients suffering from cerebrovascular diseases. It is a derivative of Periwinkle plant whose anti-inflammatory activity has been proved. It particularly inhibits TNF- $\alpha$-induced NF- $\kappa B$ activation and the subsequent induction of proinflammatory mediators. As the pathogenesis of IBD proves the potential role of TNF- $\alpha$ and NF$\kappa B$, therefore their inhibition proves that vinpocetine is a unique anti-inflammatory agent with potential in the treatment of many inflammatory diseases like IBD. No major adverse effect of vinpocetine has been reported yet which signifies its advantage over other antiinflammatory drugs. No evidence has been reported on activity of the respective drug in treatment of IBD. To assess the severity of colitis, DAI was calculated. The DAI was decreased by administration of vinpocetine at different doses and combination of sulfasalazine + vinpocetine $(360 \mathrm{mg} / \mathrm{kg}+5 \mathrm{mg} / \mathrm{kg})$ which indicated their effectiveness

Table 4: Comparison of different biochemical parameters evaluated in the study

\begin{tabular}{|c|c|c|c|c|c|c|}
\hline $\begin{array}{l}\text { Biochemical } \\
\text { parameters }\end{array}$ & $\begin{array}{l}\text { Control } \\
\text { Group I }\end{array}$ & $\begin{array}{l}\text { Acetic acid } \\
\text { Group II }\end{array}$ & $\begin{array}{l}\text { Vinpocetine } \\
\text { Group IIIA } \\
(5 \mathrm{mg} / \mathrm{kg})\end{array}$ & $\begin{array}{l}\text { Vinpocetine } \\
\text { Group IIIB } \\
(10 \mathrm{mg} / \mathrm{kg})\end{array}$ & $\begin{array}{l}\text { Sulfasalazine } \\
\text { Group IV } \\
(360 \mathrm{mg} / \mathrm{kg})\end{array}$ & $\begin{array}{l}\text { Vinpocetine+sulfasalazine } \\
\text { Group V } \\
(5 \mathrm{mg} / \mathrm{kg}+360 \mathrm{mg} / \mathrm{kg})\end{array}$ \\
\hline $\begin{array}{l}\mathrm{GSH}(\mathrm{nmol} / \mathrm{g} \text { of } \\
\text { tissue) }\end{array}$ & $33.31 \pm 0.60$ & $13.61 \pm 0.39 * a, * c, * d$ & $26.78 \pm 0.51^{* a, * b, * \mathrm{f}}$ & $28.60 \pm 0.89 * a, * \mathrm{~b}$ & $30.11 \pm 0.76^{* a, * b}$ & $29.9 \pm 0.55^{* a, * b, * e}$ \\
\hline $\begin{array}{l}\mathrm{MPO}\left(\mu \mathrm{mol} \mathrm{H} \mathrm{O}_{2}\right. \\
\text { consumed } / \mathrm{min} / \mathrm{mg} \\
\text { protein })\end{array}$ & $4.95 \pm 0.36$ & $41.76 \pm 0.774^{* \mathrm{a}, * \mathrm{~b}, * \mathrm{~d}}$ & $28.21 \pm 0.713^{* a, * b, * c}$ & $18.36 \pm 0.616^{* a, * b, * c}$ & $12.05 \pm 0.587^{* a, * b, * d}$ & $19.617 \pm 0.857 * a, * \mathrm{~b}, * \mathrm{~d}$ \\
\hline MDA (nM/g of tissue) & $5.66 \pm 0.236$ & $15.95 \pm 0.563^{* \mathrm{a}, * \mathrm{c}, * \mathrm{~d}}$ & $9.76 \pm 0.280 * \mathrm{a}, * \mathrm{~b}, * \mathrm{c}, * \mathrm{f}$ & $7.83 \pm 0.265^{* a, * b, * e}$ & $7.43 \pm 0.386^{* a, * b, * e}$ & $7.98 \pm 0.409 * \mathrm{a}, * \mathrm{~b}, * \mathrm{e}$ \\
\hline TNF- $\alpha(\mathrm{pg} / \mathrm{ml})$ & $0.038 \pm 0.007$ & $0.139 \pm 0.018^{\mathrm{a}}$ & $0.14 \pm 0.005^{\mathrm{b}}$ & $0.078 \pm 0.008^{\mathrm{b}}$ & $0.064 \pm 0.007^{\mathrm{b}}$ & $0.079 \pm 0.009^{\mathrm{b}}$ \\
\hline
\end{tabular}

The values were expressed as mean \pm SEM. ${ }^{* a} \mathrm{p}<0.05$, when compared with healthy control. ${ }^{* b} \mathrm{p}<0.05$, when compared with acetic acid control, ${ }^{* c} \mathrm{p}<0.05$, when compared with 5-ASA, ${ }^{* \mathrm{~d}} \mathrm{p}<0.05$, when compared with vinpocetine $10 \mathrm{mg} / \mathrm{kg},{ }^{* e} \mathrm{p}<0.05$, when compared with vinpocetine $5 \mathrm{mg} / \mathrm{kg}$ and ${ }^{* f}$ when compared with sulfasalazine $+5 \mathrm{mg} / \mathrm{kg}$ vinpocetine. ${ }^{\mathrm{a}} \mathrm{p}<0.05$, when compared with healthy control. ${ }^{\mathrm{b}} \mathrm{p}<0.05$, when compared with acetic acid control. The data were analyzed using one-way analysis of variance followed by Dunnett test. SEM: Standard error of mean, MDA: Malondialdehyde, MPO: Myeloperoxidase, TNF- $\alpha$ : Tumor necrosis factor- $\alpha$, GSH: Glutathione 


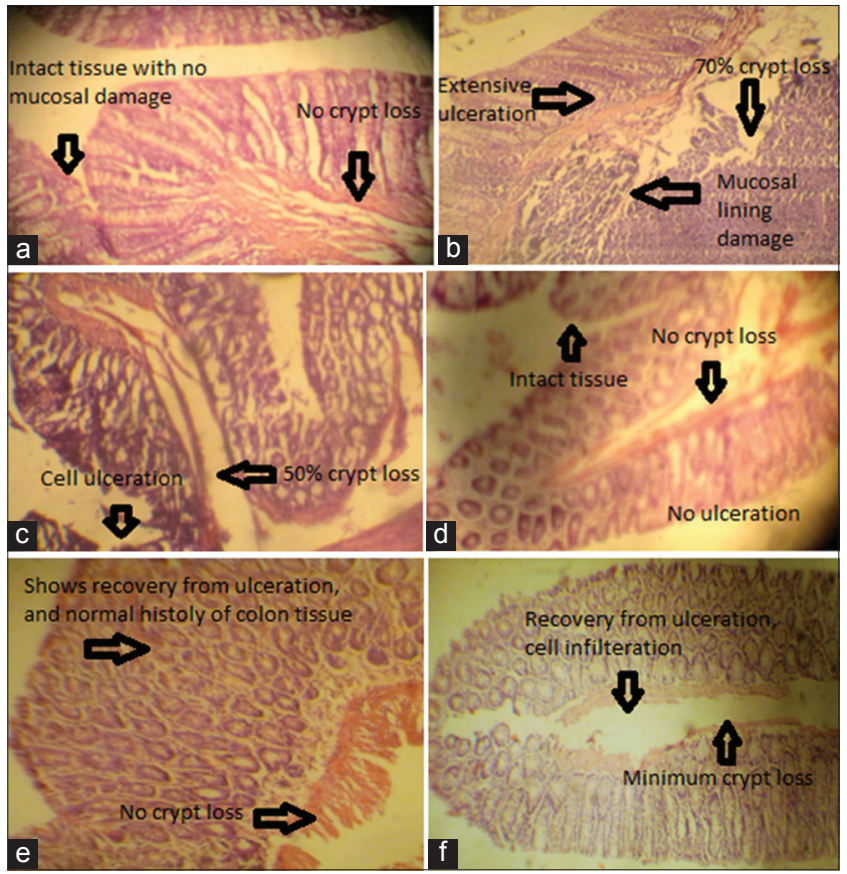

Fig. 1: Photomicrograph of the colon tissue of (a) normal control showing the normal histology of colon tissue, (b) acetic acid group showing the cell infiltration, severe inflammation and $70 \%$ crypt loss, (c) acetic acid + vinpocetine ( $5 \mathrm{mg} / \mathrm{kg}$ ): showing ulceration and crypt loss, (d) acetic acid + vinpocetine $(10 \mathrm{mg} / \mathrm{kg})$ showing recovery from ulceration, cell infiltration and minimum crypt loss, (e) acetic acid + sulfasalazine $(360 \mathrm{mg} / \mathrm{kg})$ showing normal histology of colon tissue total recovery from ulceration,

(f) acetic acid + sulfasalazine $(360 \mathrm{mg} / \mathrm{kg})+$ vinpocetine

$(5 \mathrm{mg} / \mathrm{kg})$ showing reversal of ulceration, decreased cell infiltration and minimum crypt loss $(\mathrm{H}$ and $\mathrm{E}, \times 40)$

in the treatment. These above effects may be attributed to the antiinflammatory effect of vinpocetine.

Acetic acid induced colitis is an easily inducible model of IBD, and the inflammatory phase bears some resemblance to acute human intestinal inflammation. In this study, intracolonic administration of acetic acid resulted in significant hydropsia, necrosis, erosion, and ulceration. Acetic acid treatment led to significant increase in colonic mucosal damage scores (indicative of ulceration) thereby indicating the successful reproduction of acetic acid induced colitis model. Our histological findings showed cell infiltration, inflammation, mucosal damage, and crypt loss. All the animals in acetic acid control group showed severe inflammatory changes. Histopathological scores appeared to be curtailed by administration of vinpcetine in different doses. The combination therapy of sulfasalazine + vinpocetine ( $360 \mathrm{mg} / \mathrm{kg}+5 \mathrm{mg} / \mathrm{kg}$ ) was equally effective to standard drug but not found to be the most effective treatment.

Experimental and clinical evidence has suggested that the inflamed colon undergoes substantial oxidative stress by neutrophils-derived oxidants, which contribute markedly to tissue damage. Measurement of MPO activity has been used as an indicator of neutrophil influx into inflamed gastrointestinal tissue. In our study, vinpocetine significantly decreased the MPO level in the intestinal tissue of the rats with acetic acid induced colitis, and thus, the severity of the tissue damage. MPO levels were significantly less in vinpocetine treated groups as compared to acetic acid control group; however, the levels were found to be comparably less in combination group as well. These results showed that vinpocetine was effective in treating acetic acid induced colitis, but the combination is not found to be very effective.
Furthermore, IBD has been found to be associated with an overproduction of nitric oxide (NO) by the inducible isoform of NO synthase. In this study, vinpocetine significantly increased the GSH level in the intestinal tissue of the rats with acetic acid induced colitis, and thus the severity of the tissue damage. GSH levels were significantly more in vinpocetine treated groups as compared to acetic acid control group; however, the levels were found to be comparably more in combination group as well. These results showed that vinpocetine was effective in treating acetic acid-induced colitis. Similarly, vinpocetine significantly decreased the MDA level in the intestinal tissue of the rats with acetic acid induced colitis, and thus the severity of the tissue damage. MDA levels were significantly less in vinpocetine treated groups as compared to acetic acid control group; however, the levels were found to be comparably less in combination group as well. These results showed that vinpocetine was effective in treating acetic acid-induced colitis. The combination of sulfasalazine + vinpocetine was found to be effective as compared to high dose of vinpocetine $(10 \mathrm{mg} / \mathrm{kg})$.

\section{CONCLUSION}

On the basis of this study, it was concluded that vinpocetine possessed anti-inflammatory activity and was found to be therapeutically effective in acetic acid induced UC at dose of $5 \mathrm{mg} / \mathrm{kg}$; however, more pronounced effects were observed at higher dose, i.e., $10 \mathrm{mg} / \mathrm{kg}$. The combination of sulfasalazine + vinpocetine was found to be effective as compared to high dose of vinpocetine $(10 \mathrm{mg} / \mathrm{kg})$. Hence, vinpocetine possesses the potential of an effective and promising drug for the treatment of UC.

\section{REFERENCES}

1. Baumgart DC, Carding SR. Inflammatory bowel disease: Cause and immunobiology. Lancet 2007;369(9573):1627-40.

2. Baumgart DC, Sandborn WJ. Inflammatory bowel disease: Clinical aspects and established and evolving therapies. Lancet 2007;369(9573):1641-57.

3. Sachard D. Planting the seeds of knowledge about inflammatory bowel disease: Half a century of science, prescience and prophecy from the pages of Mount Sinai's Journal. Mt Sinai J Med 2001;68:79-87.

4. Xavier RJ, Podolsky DK. Unravelling the pathogenesis of inflammatory bowel disease. Nature 2007;448(7152):427-34.

5. Lawrence MT, Macphee SJ, Papadakis MA, editors. Current Medical Diagnosis and Treatment. Chicago: McGraw Hill; 2014.

6. Chan AT, Manson JE, Albert CM, Chae CU, Rexrode KM, Curhan GC, et al. Nonsteroidal antiinflammatory drugs, acetaminophen, and the risk of cardiovascular events. Circulation 2006;113(12):1578-87.

7. Kruis W, Schreiber S, Theuer D, Brandes JW, Schütz E, Howaldt S, et al. Low dose balsalazide ( $1.5 \mathrm{~g}$ twice daily) and mesalazine $(0.5 \mathrm{~g}$ three times daily) maintained remission of ulcerative colitis but high dose balsalazide ( $3.0 \mathrm{~g}$ twice daily) was superior in preventing relapses. Gut 2001;49(6):783-9.

8. Patyar S, Prakash A, Modi M, Medhi B. Role of vinpocetine in cerebrovascular diseases. Pharmacol Rep 2011;63(3):618-28.

9. Jeon KI, Xu X, Aizawa T, Lim JH, Jono H, Kwon DS, et al. Vinpocetine inhibits NF-kappaB-dependent inflammation via an IKK-dependent but PDE-independent mechanism. Proc Natl Acad Sci U S A 2010;107(21):9795-800.

10. Hagiwara M, Endo T, Hidaka H. Effects of vinpocetine on cyclic nucleotide metabolism in vascular smooth muscle. Biochem Pharmacol 1984;33(3):453-7.

11. Abdel Salam OM, Oraby FH, Hassan NS. Vinpocetine ameliorates acute hepatic damage caused by administration of carbon tetrachloride in rats. Acta Biol Hung 2007;58(11):411-9.

12. Ghatule RR, Goel S, Gautam MK, Singh A, Joshi VK, Goel RK. Effect of Azadirachta indica leaves extract on AA-induced colitis in rats: Role of antioxidants, free radicals and myeloperoxidase. Asian Pac J Trop Dis 2012;2:S651-7.

13. Zhang DK, Cheng LN, Huang XL, Shi W, Xiang JY, Gan HT. Tetradrine ameliorates dextran-sulphate-sodium-induced colitis in mice through inhibition of nuclear factor- $\kappa \mathrm{B}$ activation. Int $\mathrm{J}$ Colorectal Dis 2009;24:5-12.

14. Wirtz S, Neufert C, Weigmann B, Neurath MF. Chemically induced 
mouse models of intestinal inflammation. Nat Protoc 2007;2(3):541-6.

15. Kojima R, Kuroda S, Ohkishi T, Nakamaru K, Hatakeyama S. Oxazolone-induced colitis in BALB/C mice: A new method to evaluate the efficacy of therapeutic agents for ulcerative colitis. J Pharmacol Sci 2004;96(3):307-13.

16. Vogel H, editor. Drug Discovery and Evaluation Pharmacological Assay. Germany: Springer; 2002.

17. Ellman GL. Tissue sulfhydryl groups. Arch Biochem Biophys 1959;82(1):70-7.
18. Krawiesz JE, Sharan P, Stenson WF. Quantitative assay to acute intestinal inflammation based on myeloperoxidase activity: Assessment of inflammation in rat and hamster model. Gastroenterology 1984;87:1344-50.

19. Ohkawa H, Ohishi N, Yagi K. Assay for lipid peroxides in animal tissues by thiobarbituric acid reaction. Anal Biochem 1979;95(2):351-8.

20. Randhawa PK, Singh K, Singh N, Jaggi AS. A review on chemicalinduced inflammatory bowel disease models in rodents. Korean $\mathrm{J}$ Physiol Pharmacol 2014;18(4):279-88. 